EPiC Series in Language and Linguistics
Volume 2, 2017, Pages 102-111
Professional and Academic Discourse:
an Interdisciplinary Perspective

\title{
Connecting Learner Needs with Academic Discourse: a Research on LSP Courses at Beginners’ Level for Students of Art History and Archaeology in German Universities
}

\author{
Debora Gay \\ Georg-August-Universtität Göttingen \\ debora.gay@phil.uni-goettingen.de
}

\begin{abstract}
The paper introduces the relevance of the Italian language in the discourses of Art History and Archaeology and its properties. Then it focuses on the Learner Needs (LN) of a specific target audience: students of Art History and Archaeology, under- and postgraduates aiming to achieve LSP competence in Italian already as beginners or quasibeginners. Being these general LN, how far is it possible to satisfy them with an LSP course on discourse relevant aspects in the academy? - The paper gives an answer to this question discussing some outcomes of a $\mathrm{PhD}$ research: in this doing, it describes the course design, learners' profiles and their performances. Finally it suggests a flexible course concept with a main focus on didactics and on refined specific LN.
\end{abstract}

\section{Introduction}

The topic of the Conference AESLA 2016 advocates for a consideration of two main interdisciplinary approaches: one oriented to epistemologies of disciplines, in which specialized discourses occur, and the other regarding the relationship between the contexts of specialized communication. Both approaches can lead to adequate options for LSP didactics. The present paper relates to a recent $\mathrm{PhD}$ research on the didactics of Italian language. First, it took in account the two interdisciplinary approaches and investigated the specialized discourses of the disciplines Art History and Archaeology, their tradition and occurrence in context. In this doing, it focused on LN. On this basis was conducted an educational research which provided empirical evidence and allowed refining the LN of Art History and Archaeology students. 


\section{The Context and the Gap}

Romance languages play an important role in the Humanities for university students. They are connected with research traditions and learning cultures. Multilingualism characterizes scientific communication in the Humanities (Österreicher 2004, 2005). In the field of Archaeology, for example, a study on multilingualism in scientific communication (Hempel 2011, 2012) showed that (1) most publications acquired by certain German universities in recent years were in Italian, not English, and (2) most papers published in 2008 on a topic like iconography appeared in English and Italian, followed by German and French. Indeed, Italian is the fourth most widely learnt language and it is learnt with cultural aims (De Mauro et al. 2002). Multilingualism in scientific communication in Art History and Archaeology can be described as the habit of writing mostly in one's own language and reading in multiple languages of specialized publications ${ }^{1}$. Therefore, Humanities students are expected to read the literature in both English and the Romance languages. This requirement is linked to the need for foreign language skills when studying abroad as under- or postgraduates. But what are the properties of the disciplinary and academic discourses of Art History and Archaeology and what do students need to learn? Which conceptual frame for Learner Needs considers target language skills? How can the gap between the students' starting competences and language goals be filled?

\section{LSP, Academic Discourse and General Learner Needs}

\subsection{Discourses of Art History, Archaeology and the Italian Language}

Italian plays an important role in the contemporary scientific communication of Archaeology and Art History, yet its relevance also lies in the centuries of literature produced by artists, art theoreticians and authors of treatises during the late Middle Age, the Renaissance, and the Baroque and Classicism periods. Therefore, most art vocabulary was originally developed in Italian, in the Italian volgare, through derivation from Latin and ancient Greek or as a new formation in artists' workshops, building sites and handicrafts communication contexts. Through the circulation of art works, treatises, artists and art theoreticians Italian art vocabulary reached other European languages directly or through the mediation of French. Borrowings and linguistic imprints from Italian characterize vocabulary of fine arts in most European languages ${ }^{2}$.

It is not easy to draw the profile of the LSP in this subject field: Art History and Archeology belong to the so called "soft" disciplines, they use a specialized vocabulary which is often not monosemic and their specialized texts are frequently characterized from individual styles ${ }^{3}$. I will consider here the specialized discourse of the two disciplines following the approach of Discourse Analysis (DA) ${ }^{4}$, which

\footnotetext{
${ }^{1}$ This is what Hempel (Hempel 2013, 2012) states for the subject field in Germany, Italy and North America. His understanding of multilingualism is also confirmed for other subject fields of the Humanities (Hempel 2013).

${ }^{2}$ Literature on this topic is copious: see Biffi 2008, 2010, 2013; Gay 2011b, 2013, in press; Motolese 2011.

${ }^{3}$ Knowledge construction in Archaeology is made from several "voices" (Joyce et al. 2002). Discourse construction can differ depending from the discipline: different grammatical devices in written texts accomplish rhetoric functions in hard- and in soft-sciences according to their epistemologies (Hyland 2011). Finally, writing styles follow also aesthetic functions of verbal language (a "mimesis" after Panofsky) in Art History and Archaeology in order to explain art works and findings (Gay 2013, in press; Hempel 2010).

${ }^{4} \mathrm{DA}$ investigates meaning construction in texts, in genres, discourse practices in social contexts, discourse communities (Bhatia 2008, 2004) and disciplinary cultures (Hyland 2004). In disciplinary cultures occur specialized discourses (Gotti 2008). DA takes into account the synchronic and diachronic dimensions of discourses and language(s) of the disciplines, as well as their epistemology and tradition. Epistemological DA investigates disciplinary traditions and cultures (Bhatia 2004). Overlapping aspects of different disciplines can be explained with the concept of interdiscursivity (Bhatia 2015, 2010; Gautier 2014), i.e. "shared characteristics across" discourse constructs (Bhatia 2012).
} 
allows seeing language learning as situated in a knowledge community and communicative competence as the key to be part of its discourses (Hyland 2006).

From the discourse perspective, Art History is a discipline with its own, quite recent research methods. Early literature about the fine arts, in which the Italian art vocabulary is used, belongs to art theory and critics or to biographic genres. At the end of the 18th century, Art History as such was a result of philosophic orientations, when Early Romanticism saw Arts as a language embedded in History (Leonhard 2011): historic research on styles followed this view. Positivist methods characterized the forthcoming time with classification and cataloguing of works, genres and forms. The discipline as a subject taught in universities in the 19th century, the contribution of different philosophies to the analysis and interpretation of fine arts, the growth of research institutes worldwide was the origin of research topics, approaches and learning cultures in different languages which further characterize the multilingualism of its discourses today.

As a younger discipline, Archaeology differs from Art History. Investigation on antiquities was developed throughout the 17th century in several European countries and languages (Kepetzis 2010; Gay 2017). After Winckelmann, Archaeology was understood as the discipline that reconstructs the history of the styles of the antiquity (Graepler 2014). Philology was the help of the new discipline since the end of the 18th century in "reading" the findings (Beyer 2010; Graepler \& Migl 2007). This is perhaps the reason why the specialized vocabulary of Archaeology borrows many terms from Latin and old Greek. Reconstruction of the past through systematic excavation, classification and cataloguing was the aim of the discipline at the time of positivist Philosophies. This generated research traditions, topics and further theoretical approaches in the academy in several countries. The theoretic and epistemic turn introduced from the New Archaeology in the second half of the 20th century moved partially towards a growing orientation to English. Nevertheless Italian language in the field is relevant because Italy is an important finding place of archaeological evidences ${ }^{5}$.

Discourses of both disciplines also occur in museums and exhibitions in the communication at a high level (e.g. among specialists, art addicts, researchers) and in the broader popularization (communication with the non-specialist audience i.e. common visitors). Specialized discourse of both disciplines in museums follows its own rules, those of museum communication and pedagogy (Ravelli 2006; Dawid \& Schlesinger 2002). This is also true for multimodal texts and hypertexts, such as museum websites. It is of some advantage that the genre, format and structure of museum texts are similar in different languages. Similarities allow learners of a foreign language to understand the texts through their knowledge of text structure and discourse organization. Most museum and exhibition publications in Italy are in Italian, when they are in a bilingual edition, the languages are Italian and English.

Finally, discourses of Art History and Archaeology and their traditions show some differences due to their epistemologies. Nevertheless, the specialized language of both disciplines can be incorporated in LSP courses for practical reasons (e.g. small student numbers). Thus, a pragmatic approach could take into account common points of both disciplines in discourse construction, text genres or specialized vocabulary despite epistemological differences and differing topics. From this perspective, a relevant question is: Does this approach fit the learner needs? How far?

\subsection{Academic Discourse and Learner Needs}

Academic discourse is involved in some of the communicative situations in Art History and Archaeology. Foreign students of Art History and Archaeology abroad need reading skills in the context of the discipline and specialized discourse to access related Italian resources like essays, textbooks,

\footnotetext{
${ }^{5}$ Researching and excavating in Italy today means working with Italian departments for cultural heritage preservation. They manage surveys and excavation permissions, archive the documentation about every conducted field research and publish contributions and findings. Communication at digging sites occurs in Italian. Also filling excavation records and related forms are in Italian. Conventionalized expressions and confidence with the forms are relevant in this case (Rossini 2008).
} 
museum catalogues. If they need to get access to old documents, artistic literature of the origins or, in general, other historical sources, they should possess reading skills at a high proficiency level. Reception and production skills at the intermediate level are needed to participate in academic courses at Italian universities. Reception in the context of the disciplinary discourse and general speaking skills are needed when visiting sites, monuments and museums in Italy, although students can also supplement with English in the latter. Moreover, Archaeology students need speaking skills and a specific discourse competence at the digging site while taking part at surveys or excavations in Italy.

These different situations shape general Learner Needs (LN), which can be better challenged taking in account the learning culture of the single countries, universities and institutes of Art History and Archaeology. In German universities, for example, Archaeology students often take part in undergraduate study trips and excavations or surveys, in order to visit the monuments and the sites. However specific LN can be different, particular and holistic.

It is common in the LSP teaching literature to broach the issue of Needs Analysis (NA) in order to design LSP courses and plan didactics. Robinson (1991) distinguishes between goal oriented needs and lacks and points out that needs have to be investigated under three aspects: Previous Knowledge, Learning Target (educational objectives, i.e. skills and competences which have to be acquired), and Learning Processes. Learner Needs Analysis (LNA) after Dudley Evans \& St. John (1998) consists of three steps: Target Situation Analysis (TSA), Learning Situation Analysis (LSA), and Present Situation Analysis (PSA), which partially correspond to the second, the first and the third aspect in Robinson. Basturkmen (2006) remarks that LN are multidimensional, connected with the learning environment on the one hand and learners as individuals on the other hand. These contributions make it clear that a LNA is necessary in order to identify specific LN beyond the general one. It can follow from the perspective of different subjects (participatory and/or non participatory) and at different steps (before, during and/or at the end of language courses). In the present investigation I used the frame provided by Dudley Evans \& St. John and tried to take in account different perspectives and steps through the research method of action research as explained below. The aim was to identify specific LN and connect them with the academic discourse of Art History and Archeology.

\section{Investigating Italian LSP-Courses at Beginners’ Level for Art History and Archaeology in German Universities}

\subsection{Courses and Research Design}

The research was undertaken at two different German universities through an action research in comparative case studies. Seven Italian courses (each was a case study per se) in two modules were held over four semesters. Courses were designed for absolute beginners or beginners with some basic competences in Italian at two different institutions ${ }^{6}$.

Different perspectives were considered in order to get a better understanding of the topic. On the one hand, the participating and the nonparticipating perspectives were taken in account. The former were the students involved in the courses, the latter was an external observer who wrote the minutes of the lessons throughout the courses. On the other hand, an exploratory, a reconstructive and a diagnostic perspective were considered. Informants in the exploratory perspective were the students, as well as professors and researchers in the same institutes involved with (at least some of) the same students in other courses. Informants of the reconstructive perspective were the students at different steps (at the

\footnotetext{
${ }^{6}$ In Westfälische Wilhelms-Universität Münster courses were held in the Language Center between 2011 and 2012, in GeorgAugust-Universität Göttingen courses were held in the Archaeology Institute between 2012 and 2013. Each module consisted of 26-28 teaching hours (i.e. 13-14 presence lessons) plus asynchronous online work.
} 
start, during and end of the courses), but also an external observer. The reconstruction of the courses also took into account documents from the courses (i.e. developed learning materials and student's learning products). Finally, student exam performances were analyzed from a diagnostic perspective. Thus, the instruments of the research were minutes of the lessons, questionnaires, interviews and written tests. Hence, the data collected were qualitative and quantitative in nature. Their amount was large ${ }^{7}$. They were analyzed separately according with the appropriated methods of qualitative and quantitative research.

Next, a cross case analysis of the outcomes was carried out for each kind of data. The triangulation of the outcomes allowed describing the courses and comparing parallel expected, yielded and perceived language competences in Italian at the end of the two modules. This comparison was followed by listening, reading and writing skills ${ }^{8}$. Furthermore, it was possible to carry out a description of several students' profiles in Italian LSP courses at beginners' level for Art History and Archaeology. The following sections will focus on the outcomes relevant for the purposes of this article.

\subsection{Profile of the Students in the Courses}

Data provided from the questionnaires at the onset of the courses displayed the shape of the students interested in Italian courses at a beginners' level for Art History and Archaeology. Most of them studied just one of the subjects: $41 \%$ only Art History, 31\% only Archaeology and while $22 \%$ had some knowledge of both disciplines, another 6\% came from other disciplines (History, Theology, Linguistics a.o.). Moreover, most of students (73\%) were undergraduates, which showed they likely did not yet have a deep knowledge of the field.

Students' self-evaluated linguistic profile revealed previous knowledge in several foreign or ancient languages (mostly English, a Romance language, French or Spanish, Latin and sometimes ancient Greek), so Italian was learnt as at least a fourth foreign language. 57\% of students declared themselves as "absolute beginners" in Italian, 30\% with some previous knowledge and 13\% with an intermediate level.

As regards NA (particularly TSA), data showed some differences in the goal oriented needs in and between the groups of the two universities. Learners were mostly Art History Students in Münster, whereas Archaeology students were prevalent in Göttingen. The former group aimed to learn Italian in order to read specialized literature; the latter group also aimed to do a study visit or excavation in Italy. Thus, reading skills in Italian were the main goal for the first group, whereas the second group sought to improve both reading and speaking skills. The PSA showed some differences within the groups related to previous subject knowledge. Finally, also the LSA stated different levels in previous knowledge of the Italian language.

The students' profile advocated a course design not too specific in subject content, focusing language structures at beginner's level, but also quick in the progression, in order to take in account students' previous language knowledge. At the same time, some differentiation was needed in each course as well as within the groups.

\subsection{Profile of the Courses}

In the courses the Italian language was taught starting from the common basis of the textbook $\mathrm{La}$ lingua dell'Arte (Gay 2011a). Further learning material was developed on the basis of relevant subject topics in each course. The core material was always a text, mostly an excerpt from a textbook, a

\footnotetext{
${ }^{7} 86$ questionnaires at the beginning of the courses, 57 at the end, 82 university course-evaluations; transcriptions of 9 group interviews with 37 different students, 80 minutes of the lessons and a corpus of 90 students' written exams (Gay in press).

${ }^{8}$ Speaking skills were trained in the courses and students gave their feedback in interviews and questionnaires. However exams consisted only of written tests.
} 
catalogue, an essay, or from a pragmatic (e.g. museums' tables, flyers of exhibitions), multimodal or hypertext (e.g. documentations on exhibitions, surveys, excavations, websites of heritage foundations and so on). Thus, language structures and vocabulary were taught functionally and in context. The functional discourse construction was then outpointed as in the CLIL didactics in order to accomplish tasks (Ellis 2003). At first simple discourse functions (e.g. describing a painting) were focused then other more complicated (e.g. comparing paintings, or telling an artist's biography ${ }^{9}$ in a chronological order) were explained. Adapting the discourse to the LN meant focusing on Art History or Archaeology, depending on the group component.

The reconstruction of the courses (after the records of the single lessons) showed also lacks in the supposed basic subject knowledge and language awareness in several students in each course. Some students needed explanations about subject topics in the texts, while others were not aware of the metalanguage used to explain grammar structures. Furthermore, individual LN due to different learning and cognitive styles, as well as high expectations in language and subject content from a minority of the students, emerged from the interviews. Thus, the major challenge was to shape the courses in language and subject content through adequate teaching methods and learning materials on the differentiated profiles and the specific learning needs of groups and single students. Courses' reconstruction shows that negotiation of meanings (Hallet \& Königs 2010; Bonnet 2007) was arranged in order to pick up learning problems and emphasize exchange and collaborative learning in the dynamic of the groups and between teacher and learners. Furthermore visualizations (images of masterpieces, buildings, figures, structures and plans), explications (PPT-Presentations with schemes and tables on grammar topics), repetitions (with adjunctive exercises) and additional exercise (with adjunctive reading texts) were provided as scaffolding instruments (Zydatiß 2010). An internal differentiation within every single group was obtained through the blended-learning course structure and the individual online workload. Finally intercomprehension strategies were broached in order to raise awareness of structures and vocabulary and gather reading strategies ${ }^{10}$. It was a way to sensitize learners to use previous language knowledge (in English, Latin or other modern languages) so that they become aware of etymologies, word formation, text structure and possible pragmatic transfer.

\subsection{Expected and Actual Performances at the End of the Courses}

The comparison of the exam forms showed that the expected target competence concerned a functional use of language in context, such as filling forms with data about masterpieces, answering questions about a textbook excerpt or a documentary, getting selected information from museum tables, writing a painting's description or a short biography. Moreover, the exam structure assessed competences in foreign language and subject content at the same time. In other words, the expected outcomes concerned discursive skills in context. Exams forms of different courses show some differences in subject content and topics, which are related to the emphasis of each single course. The expected vocabulary competence at the end of the courses was then slightly different in each test formulation, depending if the focus was on Archaeology or Art History. However the tested language structures were the same, particularly those used to accomplish the regarded discourse functions. For example, locative complements were learnt in each course and assessed in the exams in order to describe paintings or to read topographic plans used in Archaeology. Listening, reading and writing skills were

\footnotetext{
${ }^{9}$ Discourse functions express in words knowledge structures. In CLIL didactics this is a way to take in account subject content, communication, knowledge and culture at the same time (Bonnet, Breidbach \& Hallet 2013).

10 Intercomprehension as a skill has been described by the faculty to understand languages without having learnt them in a formal context (Meißner 2010). It is based on transfers, which can occur at intralingual, interlingual or pragmatic level (Meißner 2004). The different levels can interact with each other in the transfer between languages of the same family (Meißner 1998). In general, intercomprehension bridges languages and increases language awareness (Meißner 2004). Intercomprehension strategies can be taught in general and LSP courses.
} 
assessed with the same weight at the end of each course of a same module. Speaking as a skill was not assessed.

The actual performances (respectively $98 \%$ and $90 \%$ of the students passed the exams after the first and the second module) showed differences between single courses and between single students as compared to the others. In listening and reading, single courses scored better performances than the others. Triangulation of the performances with course reconstruction explains this result with a greater emphasis on listening or reading exercises in the different courses. In one case the emphasis on reading skills resulted in the best performance in this skill (22/25 mean value as compared with 17-19/25 in the other courses). In another case the emphasis on art documentaries, videos on surveys and excavations explains the higher scores in listening skills (22/25 mean value as compared with 19-20/25 in the other courses). This shows that adapting the courses to the learners keeps to light different course progression, which can result in slight differences in the performances in single skills. However, the performances in reading and listening comprehension revealed in general at least a B1 level of the Common European Framework of Reference for Languages (CEFR).

In contrast, different performances in writing had no relation to the single courses. Instead, they depended on students' individual profiles. The competence level at the end of the second module goes from an A2 to a B1-B2 level of the CEFR, related to text length (from a minimum of 143 to a maximum of 380 words for each composition), simple sentence syntax, alternation of different past tenses (only Passato prossimo in a few cases, also Imperfetto in most cases and Passato remoto in some cases), sentence structure, formulation of complex sentences and discourse construction. Triangulation of the data showed that the best performances were not necessarily related to a higher level of competence at the beginning of the course. Rather, they were related to stronger learning experience (i.e. Master and $\mathrm{PhD}$ students and previous knowledge of several languages) and higher engagement in the online work on the course platform. This also identifies the weak profiles in the courses: those of absolute beginners in Italian in the first Bachelor's semesters, having previous knowledge in only two foreign languages.

Finally exams' performances revealed higher competence level in language reception (listening and reading) than in language production (writing), particularly among absolute beginners.

\section{Refining LN and LSP Course Design after the Target Audience}

The profile of the students and courses as well as the actual performances provide an answer to the first question formulated in section 3.1. Mediating a choice of subject content, text types, genres and modality of disciplinary discourses with a pragmatic approach satisfies general LN of the target audience. The path followed in the investigated courses was a selection of single aspects of the academic discourse in which the students are involved. A diversification in subject content and vocabulary can characterize every single course depending on the target audience, but discourse constructions which are common to different topics in both disciplines have to be taken in account. In so doing discourse functions (e.g. description, narration, and comparison) are focused on and language structures and vocabulary are introduced as functional. Evidence from exams' performances shows that target learners can reach a basic discourse competence in Italian in the subjects taken in two semesters, even if they are absolute beginners.

But exam performances and course reconstruction also identified specific LN in different learner constellations and in single learners. Investigation of students and course profiles discussed in sections 4.2 and 4.3 shows that specific LN depend on previous subject knowledge, learning experience and language awareness as well as on individual factors like cognitive stiles and motivation. This suggests the answer to the second question of section 3.1: How far does this approach fit the LN? It depends on the attention to the group profile on the one hand and to the peculiarities of single learners on the other 
hand. Diversification and adaptation are needed in all groups. Further, weak learner profiles need particular support, as well as single strong profiles in a different way. Teaching methods promoting constructive dynamics in the courses can support individual profiles because they help to focus specific LN. Scaffolding provides diversification and adaptation also through individually oriented adjunct learning materials for the different learners' profiles. Performances discussed in section 4.3 show that this approach can lead to performances at different levels (for example in written skills). It takes care of the specific LN as well. This approach can fit the specific LN so far as teachers in LSP courses are able to adapt it to the learners' profiles.

Such a flexible course design for Italian courses in Art History and Archaeology at German universities opens new perspectives to LSP courses for beginners. The approach is less focused in the literature. Roelcke (2010) suggests a pragmatic approach, based on the choice of relevant language topics in the LSP. Basturkmen (2006) suggests a choice of contents, relevant for the target audience in the specialized communication, like previous literature focusing on goal oriented needs ${ }^{11}$. Outcomes of the present research show a third approach based on adaptability and flexibility. Language and content are not secondary, but only a focus on flexible didactics can take in consideration both, learners as a group and as individuals and their specific LN.

\section{Conclusions}

Connecting LN with academic discourse allows shaping LSP courses for the target learner, adapting them for different universities, broadening the range of key qualifications in the academy and being oriented towards professional discourses. If the acquisition of discourse skills, autonomy and awareness is the goal of flexible LSP courses, further language learning in regular courses or self-learning is also supported. Further research testing the drawn course design at a beginners' level is needed. The approach could be followed in the same subject field for other Romance (and not Romance) languages not (or seldom) learnt at school or in other subject fields for Italian. Future research ought to take into account the growing demand for competences after obtaining a degree and it would connect academic and professional discourse in an interdisciplinary perspective. At the same time, further investigation of the strong and weak learner profiles in LSP courses for beginners in the academy can lead to deeper understanding of their specific $\mathrm{LN}$ and to better course construction.

\section{References}

Basturkmen, H. (2006). Ideas and Options in English for Specific Purposes. Mahlwah, NJ/London: Lawrence Erlbaum Ass. Publ.

Beyer, J.M.. Archäologie. (2010). Von der Schatzsuche zur Wissenschaft. Mainz: von Zabern.

Bhatia, V.K. (2015). Critical Genre Analysis: Theoretical Preliminaries. Hermes 54: 9-20.

Bhatia, V.K. (2012). Critical Reflections on Genre Analysis. Iberica 24:17-28.

Bhatia, V.K. (2010). Interdiscursivity in professional communication. Discourse \& Communication 4-1: 32-50.

Bhatia, V.K. (2004). Words of Written Discourse. London/New York: Continuum.

Bhatia, V.K., J. Flowerdew \& H.J. Rodney (eds.) (2008). Approaches to discourse analysis. In V.K. Bhatia, J. Flowerdew \& H.J. Rodney (eds.). Advances in Discourse Studies (pp. 1-17). London/New York: Routledge.

\footnotetext{
${ }^{11}$ A similar approach has been formulated by Fluck (1992): courses can be shaped in very different ways depending on the goal oriented needs. In Basturkmen (2006), the orientation to the learner is stronger.
} 
Biffi, M. (2013). Alcune prime osservazioni sulla lingua artistica di Leonardo. Studi di Mnemofonte 10: $183-205$.

Biffi, M. (2010). Lingua dell'Arte e Critica d'Arte. Enciclopedia Italiana Treccani.

Biffi, M. (2008). La lingua tecnico-scientifica di Leonardo da Vinci. In E. Cresti (ed.), Prospettive nello studio del lessico italiano, Atti SILFI 2006 (vol. 1: 129-136). Firenze: FUP.

Bonnet, A. (2007). Fach, Sprache, Interaktion - Eine Drei-Säulen-Methodik für CLIL. FLuL 36: 126-141.

Bonnet, A., S. Breidbach \& W. Hallet. (2013). Fremdsprachlich Handeln im Sachfach: Bilinguale Lernkontexte. In G. Bach \& J.-P. Timm (eds.), Englischunterricht (pp. 172-198). Tübingen: Franke Attempo Verlag.

Dawid, E. \& R. Schlesinger (eds.) (2002). Texte in Museen und Ausstellungen. Ein Praxisleitfaden. Bielefeld: Transkriptverlag.

De Mauro, T. et al. (2002). Italiano 2000. I pubblici e le motivazioni dell'italiano diffuso tra stranieri. Roma: Bulzoni.

Dudley Evans, T. \& M.J. St John. (1998). Developments in ESP. A multi-disciplinary Approach. Cambridge University Press, pp. 121ff.

Ellis, R. (2003). Task-based Language Learning and Teaching. Oxford University Press.

Fluck, H.R. (1992). Didaktik der Fachsprachen. Aufgaben und Arbeitsfelder, Konzepte und Perspektiven im Sprachbereich Deutsch. Tübingen: Gunter Narr Verlag, pp. 24-27.

Gautier, L. (2014). Des langues de spécialité à la communication spécialisée : un nouveau paradigme de recherche à l'ntersection entre science du langage, info-com et sciences cognitives ? Etudes Interdisciplinaires en Sciences humaines (EISH) 2014/1: 225-245.

Gay, D. (in press) Die Vermittlung der italienischen Fachsprache der Kunstgeschichte und der Archäologie. Frankfurt: Peter Lang.

Gay, D. (2013). Lingua italiana e discorso sull'arte. In E. Pirvu (ed.), Discorso, identità e cultura nella lingua e nella letteratura italiana. Atti del Convegno internazionale di Studi di Craiova (pp. 21628). Craiova: Editura Universitaria.

Gay, D. (2011a). La Lingua dell'Arte. Italienisch für Studierende der Kunstgeschichte und der Archäologie. Lehrbuch. Hamburg: Buske Verlag.

Gay, D. (2011b). L’importanza dell'italiano per lo studio della Storia dell'arte. Eadem: La lingua dell'Arte. Lehrerhandbuch. Hamburg: Buske Verlag, pp. 73-81.

Gotti, M. (2008). Investigating Specialized Discourse. Bern: Peter Lang, pp. 24ff.

Graepler, D. (2014). Antikenstudium für Junge Herren von Stand: Zu Christian Gottlob Heynes archäologischer Lehrtätigkteit. In B. Bäbler, H.-G. Nesselrath (eds.), Christian Gottlob Heyne. Werk und Leistung nach zweihundert Jahren (pp. 75-108). Berlin: de Gruyter.

Graepler, D. \& J. Migl (eds.) (2007). Das Studium des schönen Altertums. Christian Gottlob Heyne und die Entstehung der klassischen Archäologie. Göttingen: Universitätsverlag.

Hallet, W. \& F.G. Königs (2010). Classroom discourse und Interaktion». In W. Hallet \& F.G. Königs (eds.), Handbuch Fremdsprachendidaktik (pp. 190-195). Seelze Velber: Klett/Kallmeyer.

Hempel, K.G. (2013). Can Scholarly Communication Be Multilingual? A Glance at Language Use in US Classical Archaeology. Humanities 2: 128-146.

Hempel, K.G. (2012). Gegenwart und Zukunft der Mehrsprachigkeit in den Geisteswissenschaften. Deutsch und Italienisch in der klassischen Archäologie. Trans-kom 5[1]: 60-123.

Hempel, K.G. (2011). Presente e futuro del plurilinguismo nelle scienze umanistiche. Il tedesco e l'italiano in archeologia classica. Lingue e Linguaggi 6: 49-88.

Hempel, K.G. (2010). Übersetzen in den Geisteswissenschaften (Deutsch / Italienisch): Fachtexte der Klassischen Archäologie. In C. Heine \& J. Engberg (eds.), Reconceptualizing LSP. Online proceedings of the XVII European LSP Symposium 2009. 
Hyland, K. (2011). Disciplines and discourses: Social interaction in the construction of knowledge. In D. Starke-Meyerring et al. (eds.), Writing in the knowledge society (pp. 193-214). West Lafayette, IN: Parlor Press and WAC Clearinghouse.

Hyland, K. (2006). Disciplinary Differences: Language Variation in Academic Discourses. In K. Hyland, K. \& M. Bondi (eds.), Academic Discourse across Disciplines (pp. 17-45). Bern: Peter Lang.

Hyland, K. (2004). Disciplinary Discourses: Social Interactions in Academic Writing. University of Michigan Press, pp. 8-12.

Joyce, R. et al. (2002). The Languages of Archaeology: Dialogue, Narrative, and Writing. Oxford, UK, and Malden, MA: Blackwell.

Kepetzis, E. (2010). Persönliches Erleben und neue Lesbarkeiten. Athenreisen in den 1670er Jahren. In D. Boschung \& E. Kleinschmidt (eds.). Lesbarkeiten. Antikerezeption zwischen Barock und Aufklärung (pp. 11-36). Würzburg: Königshausen \& Neumann.

Leonhard, K. (2011). Konstruktion von Kunstgeschichte. Schellings Philosophie der Kunst und die Trennung der Disziplinen. In P. Ziche and G.F. Frigo (eds.), Die bessere Richtung der Wissenschaften (pp. 343-405). Stuttgart-Bad Cannstatt: Frommann Holzboog.

Meißner, F.J. (2010). Interkomprehension. In C. Surkamp (ed.), Metzler Lexikon Fremdsprachendidaktik (pp. 120-121). Stuttgart-Weimar: Verlag J.B. Metzler.

Meißner, F.J. (2004). Transfer und Transferieren. Anleitungen zum Interkomprehensionsunterricht. In H.G. Klein \& D. Rudtke (eds.), Neuere Forschungen zur europäischen Interkomprehension (pp. 3966). Aachen: Shaker.

Meißner, F.J. (2004). Introduction à la didactique de l'eurocomprehension. In F.J. Meißner, C. Meißner, H.G. Klein \& T.D. Stegmann (eds.), EuroComRom - Les sept tamis. Lire les langues romanes dès le départ (pp. 7-140). Aachen: Shaker.

Meißner, F.J. (1998). Transfer beim Erwerb einer weiteren romanischen Fremdsprache: das mehrsprachige mentale Lexikon. In F.J. Meißner \& M. Reinfried (eds.), Mehrsprachigkeits-Didaktik. Konzepte, Analysen, Lehrerfahrungen mit romanischen Fremdsprachen (pp. 45-67). Tübingen: Narr.

Motolese, M. (2011). Appunti per una storia dell'italiano in Europa in ambito artistico (secc. XVXVII). Studi linguistici italiani 37-1: 39-55.

Österreicher, W. (2004). Mehrsprachigkeit als Bedingung geisteswissenschaftlicher Produktivität und die Aufgabe einer Hierarchisierung der europäischen Sprachen. In D. Jakob, T. Krefeld \& W. Oesterreicher (eds.), Sprache, Bewußtsein, Stil. Theoretische und historische Perspektiven (pp. 97-112). Tübingen: Narr.

Österreicher, W. (2005). Europäische Mehrsprachigkeit und die Sprache der Wissenschaften. In U. Pörsken (ed.), Die Wissenschaft spricht Englisch? Versuch einer Standortbestimmung (pp. 81-92). Göttingen: Wallstein Verlag.

Ravelli, L.J. (2006). Museum Texts: Communication framework. Oxon/New York: Routledge.

Robinson, P.C. (1991). ESP Today: A Practitioner's Guide. Hemel Hempstead: Prentice Hall.

Roelcke, T. (2010). Fachsprachen, Berlin: Erich-Schmidt-Verlag, pp. 170ff.

Rossini, G. (2008). La Scheda U.S. Perché sul saggio non si scrive il saggio ... Studi di Glottodidattica 2(2): 101-122.

Zydatiß, W. (2010). Scaffolding. In C. Surkamp (ed.), Metzler Lexikon. Handbuch Fremdsprachendidaktik (pp. 258-259). Stuttgart-Weimar: Verlag J.B. Metzler. 